Dept. of Microbiology,

Fac. Vet. Med., Suez Canal Univ.

\title{
SOME STUDIES ON TAIL AND FIN ROT DISEASE AMONG CULTURED TILAPIA FISHES
}

(With 3 Tables and One Figure)

\author{
By \\ A. A. EL-ATTAR and M. MOUSTAFA * \\ * Dept. of Animal and Fish Med., Fac. of Vet. Med., Cairo Univ. \\ (Received at 8/7/1996) \\ دراسة على مرض تعفن الأيل والزعنفة في أسماك البلطي المستزرعه \\ عرفه العطار ، محد مصطفى
}



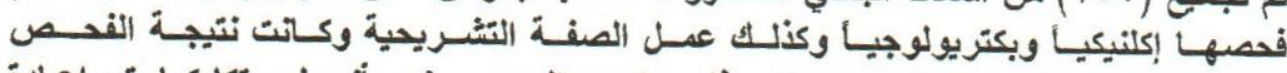

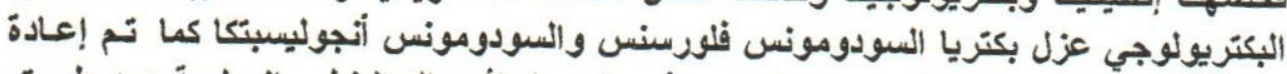



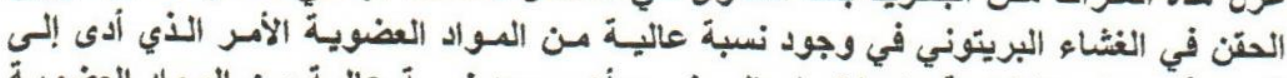

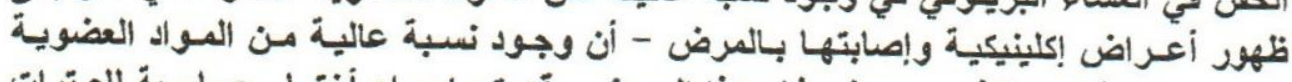

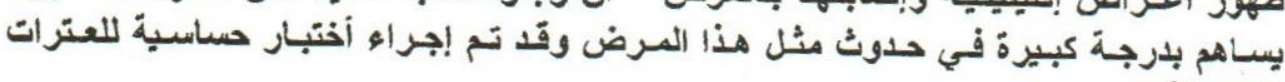

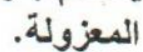

\section{SUMMARY}

A total of 150 cultured Nile tilapia (Oreochromis niloticus) fish were affected by the tail and fin rot disease were obtained. These fish were subjected to clinical, P.M. and bacteriological examination. The bacterial isolates were morophologically and biochemically related to Pseudomonas fluroscens \& Pseudomonas anguilliseptica. Reisolation of both arganisms were recovered after the experimental infection of healthy live $O$. niloticus by intraperitoneal route accompanied by high organic matter nearly revealing the some clinical signs and lesions. High organic matter is a major stress 
factor for occurence of such dangerous disease. Besides, the antibiogram of the recovered isolates was attempted.

Keywords: Tilapa fishes-Tail and fin rot

\section{INTRODUCTION}

Microbial infection of freshwater fishes are very important and amongest of it, the bacterial diseases which are the most important ones of them. Bacterial diseases cause great losses in both production and industry of fish. Tail and fin rot disease in fish is incriminated in outbreaks of bacterial haemorrhagic septiceamia (Khan, 1981; Kabata, 1985, Austin and Austin, 1987, Fernandez et $\underline{\text { al., }} 1990$ and Plumb, 1994). This study was designed to isolate and identify the causative agents of such disease in cultured Nile bolti, O. niloticus as well as clinical picture, gross lesions, pathogenicity and a trial for treatmemt.

\section{MATERIAL and METHODS}

\section{Fish:}

A total number of 150 Nile bolti, $O$. niloticus were obtained alive from fish Hatcharies at Abbasa, Sharkia Governarate, showing the typical signs and gross lesions of tail and fin rot disease according to the descriptions adopted by Egusa (1992).

\section{Bacterial isolation :}

Squash smear preperations were made from various organs of diseased fish and cultivated on different selective media \{Cetrimed agar, Rimler shotts agar (RS), MacConkey's agar and Brain heart Infusion agar (BHI)\}. The plates were inocubated at $25^{\circ} \mathrm{C}$ for 24 hours. Suspected pure colonies were transferred into nutrient slants for further identification.

\section{Identification of isolates :}

This included examination of morphological characters, colonial and growth appearance and biochamical tests according to Lennette et al., (1980) and Krieg and Holt (1984).

\section{Experimental Infection :}

A total of 30 apparently healthy live $\boldsymbol{O}$. niloticus fish were used for intraperitoneal (I/P) inoculation with previously isolated fish pathogens. The fish were divided into three equal groups each of which 10 . They were kept in prepared glass aquaria with aerated chlorine free tap water. Water 
temperature was thermostatically adjusted at $25 \mathrm{C}^{\circ} \pm 1$. The aquaria were left without using filters to obtain high organic matter and $\mathrm{pH}$. fishes were adapted for one week before inoculation. Intraperitoneal inoculation of the isolated pathogens was done according to Lucky (1977) group 1 with $0.5 \mathrm{ml}$ of 24 hours broth culture (total bacterial count $3 \times 10^{7} / \mathrm{ml}$ ) of $P$. fluorscens in the first group and (group 2) $0.5 \mathrm{ml}$. of 24 hours both culture (total bacterial count $2 \times 10^{8} / \mathrm{ml}$ ) of $\boldsymbol{P}$. anguilliseptica while the third group was served as control and inoculated $\mathrm{I} / \mathrm{P} 0.5 \mathrm{ml}$ of sterile broth. Reisolation of the same bacteria was attemped. Besides, recording the clinical signs, the P.M lesions as well as morbidity and mortality rates.

\section{Sensitivity test :}

The antibiograms of the recovered pathogens were done using the disc diffusion method of Bauer et al (1966). The interpretation of zones of inhibition were estimated according to the limits given by Finegold and Martin (1982) and Bio-merieux (1984).

\section{Clinical examination :}

\section{RESULTS}

Diseased fish showed loss of balance, frayed and torn tail and fins, eye cloudness, scale detachment and skin discolouration with scattered haemorrhages allover the body surface fig. (1).

\section{Postmortem examination :}

Most of the internal organs were congested and enlarged and abdominal ascitis with reddish serious fluid.

\section{Bacteriological examination :}

The results of bacterial examination (morphological, microscopical and biochemical) were recorded in Table (1). The isolates were identified as

$\boldsymbol{P}$. fluorscens and $\boldsymbol{P}$. anguilliseptica.

\section{Experimental infection:}

The I/P infection fish showed nearly the same clinical signs observed in natural infection indicating the tail and fin rot disease. The infected bacteria were reisolated again from all freshly dead and clinically diseased fish (Table2)

\section{Drug sensitivity :}

The drug sensitivity test revealed that $\boldsymbol{P}$. fluorscens was highly sensitive to oxytetracycline and chloramphenicol, while it was resistant to sulpha and penicillin. Regarding $\boldsymbol{P}$. anguilliseptica it was highly sensitive to chloramphenicol. 


\section{DISCUSSION}

From the clinical and postmorterm examination of cultured naturally infected $\boldsymbol{O}$. niloticus fish, the present findings appeared nearly simulate the results given by Shotts and Bullock (1975), Casba et al. (1981) and Roberts (1989). According to the bacterial examination of such fish, the bacterial isolates were belonged to $\boldsymbol{P}$. fluorescens and $\boldsymbol{P}$. anguilliseptica which agree with the finding of Ahne et al. (1982) Post (1987) and Inglis et al., (1993). Concerning the I/P inoculation, the experimental fishes showed nearly similar clinical signs and lesions like those observed in natural infection with tail and fin rot disease. The high mortality rate $(60 \%)$ was attributed to the increase of waste products and organic matter which leads to high $\mathrm{pH}$ acting as predisposing factor for infection (Eissa et al., 1991) as well as toxic proteinase enzymes produced by $\boldsymbol{P}$. fluorescens and $\boldsymbol{P}$. anguilliseptica throughtout the fish body by the blood stream, this serving to destroy the body tissue, and attack the endothelial lining of the body vessels ( $\mathrm{Li}$ and Flemming 1967). These results support the findings given by Eissa and AbdAlla (1991) and Eissa et al., (1991). Regarding the drug sensitivty test, it was revealed that $\boldsymbol{P}$. fluorscens strains were highly sensitive to oxytetracycline and chloramphencol while they were resistant to sulpha and penicillin. Such results are more or less agree with that reported by Fernandez et al., (1990) and Emad (1992). It was concluded that cultured $\boldsymbol{O}$. niloticus fish must be checked for $\boldsymbol{P}$. fluorscens and $\boldsymbol{P}$. angiulliseptica infections before transportation from infected fish farm to another uninfected one.

\section{REFERENCES}

Ahne, W; Popp. W. and Hoffmann, R. (1982) : pseudomonas fluorscens as a pathogen of tonch. Bull. Eur. Ass. Fish path. 4, 56-57.

Austin, B. and Austin, D.A. (1987) : Bacterial fish pathogns disease in farmed and wild fish.Ellis harwood limited Eng., P. 250-260.

Bauer, A.W.; Kirby, W.M.; Sherris, J.C. and Turk (1966) : Antibiotic sucsceptiblity testing by a standarized single disc method. Am. J. Clin. Pathol. 45, 495-496.

Bio-Merieux (1984) : Laboratory reagents and products. Macly-L- Etoile 69260 Charbonmiees, Les Bains, France. 
Csaba, C. : Prigli, M,I Bekesi, Bajmocy, E. and Fazokas, B (1981) Septicaemia in silver carp and big head caused by $P$. fluorscens. Fish pathol. \& Env Euro. Polv, 111-123.

Eissa, I.A.M. and Abd-Alla, O.A (1991) :Some studies on the defence mechanism of $\boldsymbol{O}$. niloticus fish exposed to Aerolein pollution experimentally infected by $A$. hyphrophila. Assiut. Vet. Med. J., 26, 51, 174-181.

Eissa, I.A.M., Badran, A. F. and Moustafa, M. (1991) : An outbreak of Red mouth disease among cultured freshwater fishes in Ismailia Governorate. Alex. J. Vet. Sci, 6 \& 7, 109-119.

Emad, S.A. (1992) : Studies on Pseudomnas infection in fresh waster fish tilapia nilotica. M.V. \& C. Assuit Univ.

Fernandez, A.I., Rodriguez, L.A. and Nieto, T. P. (1990) : Characterization of Pseudomonas strains producing septicaemia in rainbow trout cultured in the North West of Spain. Bull. Eur. Ass. Fish. Pathol. $10,5,133$.

Finegold, S. M. and Martin, W. J. (1982) : Diagnostic Microbiology 6th Ed. the C.V. Mos by Company, .S.A.

Inglis, V.; Roberts, R. and Bromage, N. (1993) : Bacterial disease of fish. Blackwell Sci. Publ. Oxford, London.

Kabata, Z. (1985) : Parasites and disease of fish cultued in the tropico. Taylor \& francis London and Philadelphia Int. Develop. Res. Council, 1st Ed.

Khan, R.A., Campbell, J. and Lear, H.(1981) : Mortality in captive Atlantic Cod associated with fin rot disease J. of Wild life Dis. 17, 4, 521527.

Krieg, N.R. and Halt, J.G. (1948): Bergey's Manual of systemic bacteriology. Williams and Wilkins, Blatimore, London, 1 $\underline{\text { st Ed. }}$

Lennete, E.H., Balows, A.; Hauster, W. and Traunt, J. J.P (1980) : Manual of clinical microbiology. Amer. Soc. Macro. Washington, D. C. 2nd Ed.

Li, H.F. and Flemming, C. (1967) : A proteolytic Pseudomonas from skin lesions of rainbow trout. Conad. J. of Microbiol., 13, 405-416.

Lucky, Z. (1977) : Methods for the diagnosis of fish diseases Amerind publ. Co PVT, Ltd, New York, $1 \underline{\text { st }}$ Ed.

Plumb, A.J. (1994) : Health maintenance of Cultured fish principal microbial disease. CRC press, Inc. London.

Post, G. (1987) : Text book of fish health. TFH publication, Inc. Ltd, USA 2nd Ed. 

Roberts, R.J (1989): Fish pathology. Baillier, ti, London Philadelphia, Sydeny, Tronto, 2nd. ed.

Shots; E.B. and Bulock, G.L. (1975) : Bacterial disease of fish. Diagnostic procedure for Gram negative pathogens. J. fish Bact of Canada, 32, 124-1247.

Fig.. 1: Showing generalized erythema \& tail rot with scale loss in cultured $O$. niloticus fish 

Assiut Vet. Med. J. Vol. 35 No. 70, July 1996

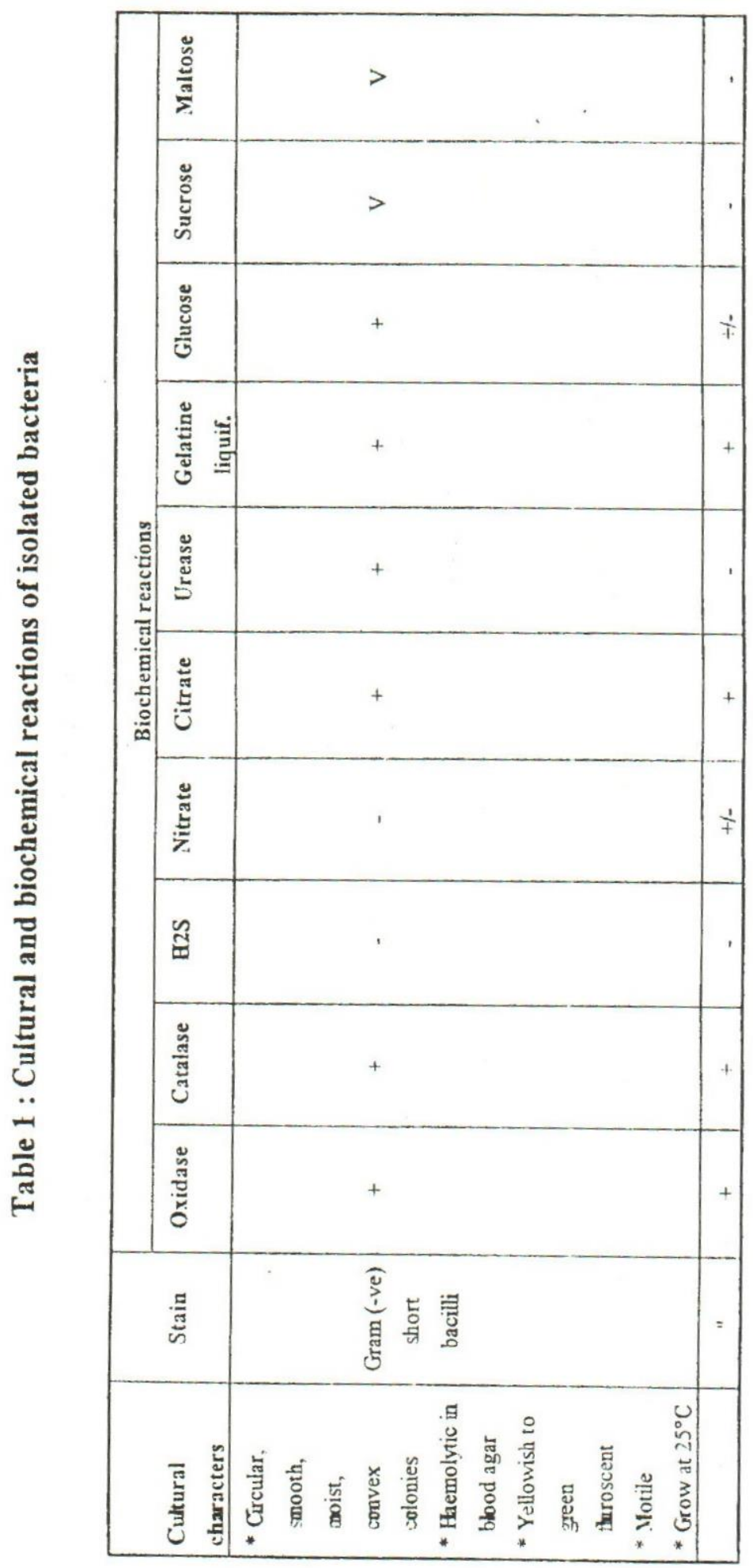




\section{Assiut Vet. Med. J. Vol. 35 No. 70, July 1996}
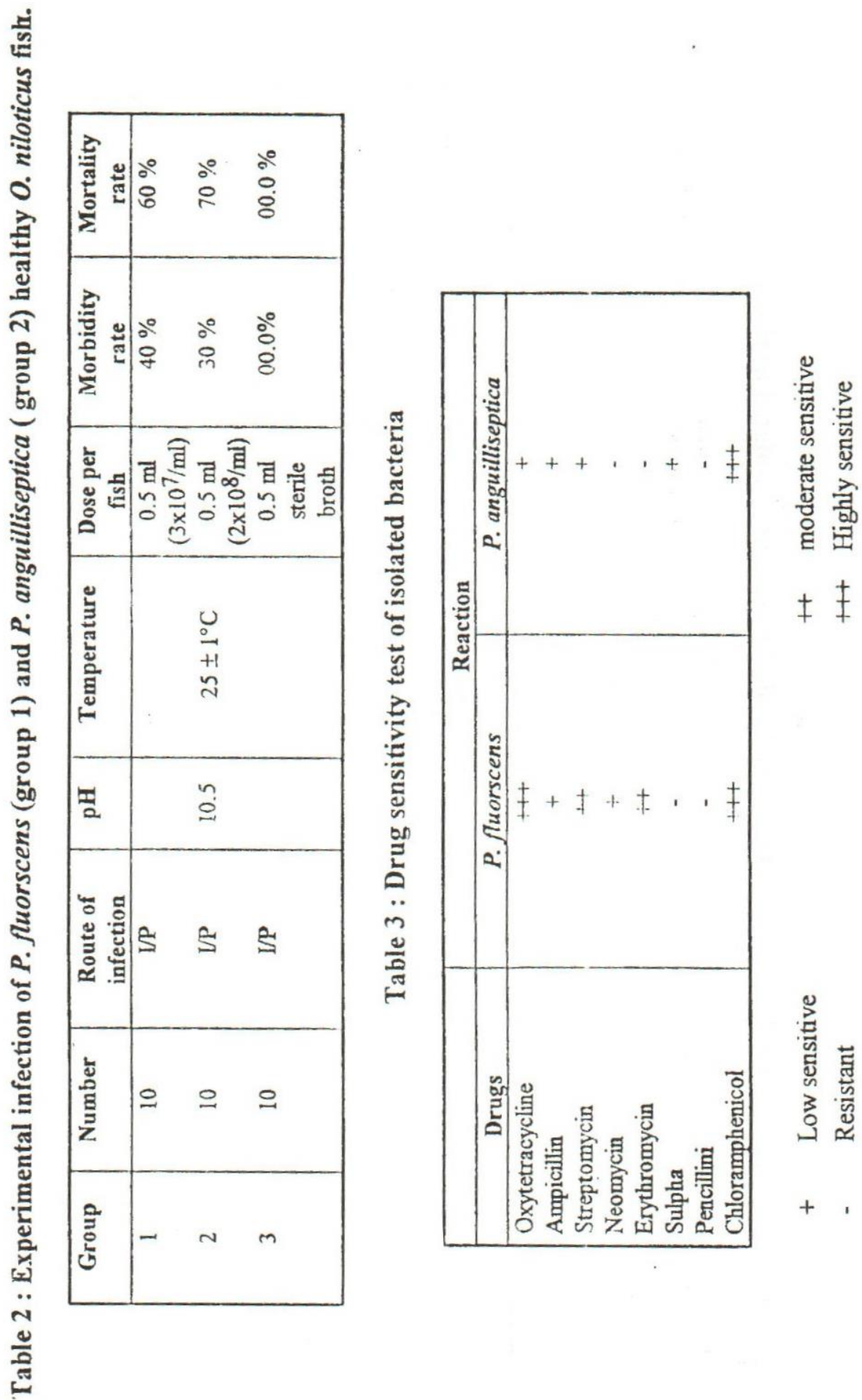

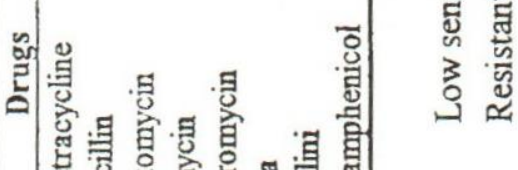

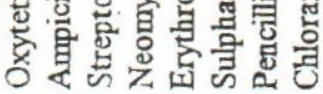

